\title{
Línguas Jndígenas \& Língua Portuguesa em Comunidades Jndígenas do Sul de Mato Grosso do Sul
}

\author{
Indigenous Languages \& Portuguese Language in Indigenous \\ Communities in the Southern of Mato Grosso do Sul
}

Marilze Tavares*

Resumo: A maioria dos indígenas adultos das comunidades Guarani de Mato Grosso do Sul é bilíngue - tem uma das línguas indígenas, guarani kaiowá ou guarani ñandeva, como língua materna e a língua portuguesa como segunda língua. Somente alguns idosos e crianças pequenas que ainda não vão para a escola falam apenas a língua materna. Neste trabalho, procuramos verificar que impressões os falantes demonstram ter de cada uma dessas línguas e que importância atribuem a cada uma delas. A análise dos dados, isto é, dos depoimentos dos falantes que participaram da pesquisa, mostrou que a língua materna está intimamente relacionada com a expressão da cultura tradicional; em geral, os indígenas afirmam que as línguas indígenas estão sendo transmitidas às novas gerações e, portanto, preservadas de forma adequada nas duas comunidades. Já a língua portuguesa também é considerada muito importante por todos os informantes, sendo a motivação principal de seu ensino/aprendizado a necessidade de contato com a população não indígena. Os resultados desta pesquisa poderão contribuir para compreendermos, entre outras, questões relacionadas ao futuro dessas línguas indígenas e da língua portuguesa nas comunidades investigadas.

\footnotetext{
${ }^{1}$ Mestre em Estudos Linguísticos pela Universidade Federal de Mato Grosso do Sul (2004). Doutora em Estudos da Linguagem pela Universidade Estadual de Londrina (2015). Professora efetiva do curso de Letras da Universidade Federal da Grande Dourados (UFGD).
} 
Palavras-chave: Língua guarani kaiowá. Língua guarani ñandeva. Língua portuguesa.

Abstract: Most part of indigenous adults in the Guarani communities of Mato Grosso do Sul is bilingual and has one of the indigenous languages, Guarani Kaiowá or Guarani Ñandeva, as their mother tongue and Portuguese as a second language; only a few elderly and young children still who do not go to school speak only the mother tongue. In this paper, we try to verify which impression the speakers have for each of these languages and the importance they attribute to each one of them. Data analysis showed that the mother tongue is closely related to the expression of their traditional culture; in general, the indigenous claim their languages are being transmitted to new generations, and therefore preserved in an appropriate manner in the two communities. The Portuguese is also considered very important by all informants and the main motivation for its teaching/learning is the need to contact with the non-indigenous population. These results may help us understand issues related to the future of these indigenous languages and Portuguese language in the investigated communities.

Keywords: Kaiowa Guarani language. Ñandeva Guarani language. Portuguese language.

\section{Introdução}

De acordo com o Censo 2010, realizado pelo Instituto Brasileiro de Geografia e Estatísticas (IBGE), o Brasil tem 896,9 mil indígenas em todo o território nacional, somando-se a população residente tanto em terras indígenas $(63,8 \%)$ quanto em cidades (36,2\%). Do total, 817,9 mil se autodeclararam índios no quesito cor ou raça e 78,9 mil, embora se declarassem de outra cor ou raça, principalmente parda $(67,5 \%)$, consideram-se indígenas pelas tradições e costumes.

A partir da mesma contagem da população indígena, o Censo 2010 verificou também que Mato Grosso do Sul continua sendo o estado que possui a segunda maior população indígena do Brasil. A última contagem 
realizada, mostrou que os indígenas do estado somariam $73.295^{1}$. Os grupos étnicos que ainda podem ser encontrados na região são os Guarani, os

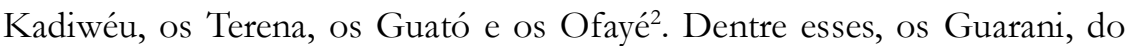
subgrupo Kaiowá, são os mais numerosos (43.401), estando entre as 15 etnias com maior número de indígenas no Brasil ${ }^{3}$. Entre as informações divulgadas pelo IBGE, não localizamos os números relativos, em específico, à população Guarani Ñandeva (que também nos interessaria no contexto deste trabalho).

A maioria dessa população tem em comum o fato de estar em contato muito frequente e direto com a população não indígena. Entre várias outras consequências desse contato está a instauração de uma situação de bilinguismo por parte da comunidade indígena. Convém esclarecer, neste contexto, que por bilinguismo estamos entendendo a coexistência de duas línguas que são utilizadas de forma alternativa pelos falantes, conforme as exigências das situações em que se encontram. No caso das comunidades indígenas com as quais trabalhamos, os indígenas têm como língua materna o guarani kaiowá (na aldeia Panambizinho/Dourados) ou guarani ñandeva (na aldeia Porto Lindo/Japorã), e, como segunda língua, a língua portuguesa que, como sabemos, é majoritária e utilizada em todo o entorno das comunidades indígenas.

Em outra pesquisa de nossa responsabilidade (TAVARES, 2015), cujos resultados ainda não foram publicados, ocupamo-nos, dentre outras questões, das impressões de indígenas Guarani Kaiowá e Guarani Ñandeva de Mato Grosso do Sul, falantes bilíngues, a respeito das línguas indígenas e da língua portuguesa utilizadas por eles. Neste texto, pretendemos, então, divulgar, parte das reflexões que fizemos a partir daquela pesquisa.

${ }^{1}$ De acordo com o Censo 2010, as cinco maiores populações indígenas, além da de Mato Grosso do Sul, estão nos seguintes estados: Amazonas, 168.680; Bahia, 56.381; Pernambuco, 53.284; Roraima, 49.637; Mato Grosso, 42.538. A menor população está no Rio Grande do Norte, 2.597.

${ }^{2}$ Martins (2002) explica que os Kaiapó Meridional e os Payaguá - que às vezes são citados como grupos indígenas do Mato Grosso do Sul - já estariam extintos da região desde meados do século XIX.

${ }^{3}$ Disponível em <http://bit.do/cUFPR>. Acesso em: 18 fev. 2014. 
Nosso objetivo principal, neste texto, é apresentar os resultados das análises que fizemos de depoimentos de falantes indígenas sobre a tão comentada importância da preservação e transmissão das línguas indígenas para as novas gerações e sobre o nível de importância que eles atribuem ao aprendizado e ao uso da língua portuguesa.

$\mathrm{Na}$ sequência esclarecemos os aspectos metodológicos essenciais para melhor compreensão das discussões que serão apresentadas.

\section{As Comunidades Indígenas, os Informantes e a Coleta dos Dados}

Esta pesquisa, conforme já sinalizado, foi realizada em duas comunidades do sul de Mato Grosso do Sul: aldeia Panambizinho e aldeia Porto Lindo.

A aldeia Panambizinho localiza-se no município de Dourados/MS, no distrito de Panambi, à margem esquerda do córrego Laranja Doce, afluente do Rio Brilhante. Em relação às demais aldeias de Dourados (Jaguapiru e Bororó), é a mais distante da área urbana, estando a aproximadamente $23 \mathrm{~km}$. Apesar disso, consideramos fácil o acesso a ela, uma vez que a estrada é pavimentada até a entrada da aldeia e as vias no interior da aldeia são relativamente bem conservadas. Nessa comunidade, de acordo com seus moradores, vivem apenas indígenas Guarani Kaiowá. Segundo informações divulgadas pelo Censo de 2010, a população do distrito de Panambi é de 1.021 habitantes e a aldeia Panambizinho, localizada nesse distrito, possui uma população de 452 indígenas. O contingente total do distrito é de 1.473 habitantes.

Já a aldeia Porto Lindo situa-se a $25 \mathrm{~km}$ da sede do município de Japorã/MS e nela vivem, de acordo com os próprios moradores, essencialmente indígenas da etnia Guarani Nandeva. O acesso a essa comunidade é um pouco mais difícil em relação ao acesso à comunidade Guarani Kaiowá de Dourados, já mencionada. A estrada que leva até a aldeia não é asfaltada e, dependendo da época, há trechos com muitos buracos. Segundo dados do Censo 2010, Japorã possui uma população de 7.731 pessoas, sendo que, desse total, 49,4\% (3.822 habitantes) se autodeclararam indígenas.

Optamos por duas comunidades pela vantagem de termos, para a pesquisa, representantes dos dois subgrugos Guarani existentes no estado. E 
por essas duas, em especial, por serem consideradas mais tradicionais, por terem menos contato com outros grupos indígenas e por estarem mais distantes da área urbana. Poderíamos ter optado, por exemplo, pelas aldeias Jaguapiru e Bororó, uma anexa à outra, as duas localizadas a pouco mais de $3 \mathrm{~km}$ da área urbana de Dourados; entretanto, nessas comunidades convivem, muito proximamente, Guarani Kaiowá, Guarani Nandeva, Terena e não indígenas, geralmente casados com indígenas. Nessas duas aldeias (Jaguapiru e Bororó), a situação linguística é mais complexa, uma vez que nelas coexistem quatro línguas! Como nosso foco era a relação da língua materna com a segunda língua, consideramos as duas comunidades selecionadas (Panambizinho e Porto Lindo) mais adequadas à pesquisa.

Após definirmos as comunidades, decidimos qual seria o perfil de informante que mais contribuiria para nos ajudar a refletir sobre as questões propostas para este trabalho. Optamos, então, por ouvir 12 indígenas adultos - 6 Guarani Kaiowá e 6 Guarani Nandeva, divididos entre homens e mulheres, professores graduados ou professores em formação.

Inicialmente procedemos a algumas visitas para conhecermos as duas aldeias e, após essa fase de visitas, passamos às entrevistas. Esse procedimento ocorreu por meio do encontro entre a pesquisadora e os informantes. De acordo com Marconi e Lakatos (2010, p. 178), trata-se de "um procedimento utilizado na investigação social, para a coleta de dados ou para ajudar no diagnóstico ou no tratamento de um problema social". Entre alguns dos objetivos da entrevista, de acordo com Selltiz et al. (1965 apud MARCONI; LAKATOS, 2010, p. 179), estão a "determinação das opiniões sobre os fatos", com o intuito conhecer o que as pessoas pensam ou acreditam que os fatos sejam. Assim, consideramos esse o melhor método, tendo em vista nossos objetivos.

Para gravarmos os depoimentos/opiniões sobre as línguas utilizadas nas comunidades, perguntamos diretamente aos informantes se eles consideravam importante ou não (e em que medida) preservar e transmitir às novas gerações a língua materna indígena; depois, perguntamos suas opiniões sobre a relevância ou não (e em que medida) de se aprender a língua portuguesa e os seus motivos.

As entrevistas foram gravadas em gravador digital e, posteriormente, transcritas pela pesquisadora. Embora obtivéssemos autorização para utilizar 
as informações para pesquisa e divulgar os resultados, optamos por não utilizar os nomes reais dos informantes (os nomes que aparecem no final dos depoimentos na seção de análise são fictícios; já a idade e a etnia informadas são reais).

Para efeito de esclarecimento, lembramos que os Guarani Kaiowá, de modo geral, autodenominam-se apenas Kaiowá, e os Guarani Ñandeva, apenas Guarani. Para nos prevenirmos de qualquer mal-entendido em relação à denominação desses subgrupos, neste trabalho utilizamos a denominação composta, que também é reconhecida pelos indígenas.

Passemos às reflexões realizadas a partir dos depoimentos coletados.

\section{Discussão dos Resultados}

\subsection{Sobre a preservação/transmissão das línguas indígenas}

Os indígenas dos dois subgrupos étnicos, Guarani Kaiowá e Guarani Nandeva, geralmente são bastante enfáticos quando falam de preservação e transmissão das línguas indígenas, afirmando que consideram essencial preservar e ensinar a língua materna. Na sequência, transcrevemos três trechos que exemplificam o pensamento verificado entre os indígenas colaboradores desta pesquisa.

1. Sem dúvida é importante preservar a nossa língua! As crianças aqui já nascem falando a língua guarani! (Risos...). Pode observar. Você não vai ouvir nenhuma criança falando, entre elas, o português. A gente incentiva e ensina a falar em guarani. Nós temos uma cultura diferente, um modo de ser diferente. Tudo bem que hoje nós temos casa de alvenaria, temos móveis, temos carros, mas a nossa língua, nós não vamos deixar não. O que é uma pessoa sem língua? É morto, né? Sem identidade. (Orlando, 34 anos, Guarani Nandeva)

2. A língua para nós é muito importante, inclusive aqui na escola nós ensinamos a língua kaiowá. Todas as crianças aprendem em casa e aqui na escola também a gente ensina. Todo mundo fala kaiowá aqui na Panambizinho e quando sai também. A gente só não fala com quem não sabe falar. (Antônio, 42 anos, Guarani Kaiowá) 
3. A língua é o que temos de mais importante, né? Sem a língua não tem reza, não tem canto, não tem festa. Quer dizer, até pode ter, mas não será mais a mesma coisa, né? Eu faço questão de conversar em guarani com todas as crianças para elas aprenderem mesmo. E com os adultos que sabem também. Quando não sabem não tem jeito. A gente fica bem feliz também quando alguém que não é índio quer aprender a nossa língua. Você, por exemplo, quer aprender, né? (Célia, 33 anos, Guarani Nandeva)

Conforme se verifica nos trechos 1, 2 e 3, tanto os informantes Guarani Ñandeva quanto o informante Guarani Kaiowá demonstram segurança ao emitirem suas opiniões sobre a importância da preservação e transmissão da língua materna. O que os informantes afirmam, sobre as crianças pequenas falarem a língua materna, pudemos observar pessoalmente durante as visitas nas comunidades indígenas. Muitas, sobretudo aquelas que ainda não vão para escola, só falam a língua indígena, mas, de acordo com outros informantes, existem também aquelas crianças que aprendem português ouvindo rádio e assistindo à televisão. Vale reiterar que todos os indígenas que participaram desta pesquisa são falantes de uma das duas línguas indígenas (guarani kaiowá ou guarani ñandeva) e da língua portuguesa.

No trecho 2, o informante menciona a escola como aliada no ensino da língua materna indígena. Da mesma forma, outros informantes, durante conversas informais, nos explicam que as escolas alfabetizam em língua materna e só depois começam a trabalhar com a segunda língua, o português. Isso, segundo eles, contribui para a vitalidade das línguas indígenas nessas comunidades.

Conforme o trecho 3, para a informante Guarani Ñandeva, a língua materna é muito importante para a sua comunidade porque está intimamente relacionada com outros elementos da cultura ("reza", "canto", "festa”). Para ela, sem a língua esses outros elementos não existiriam mais na cultura, ou, se existissem, não existiriam mais da mesma forma.

Ainda nesse trecho 2, e também no 3, os informantes das duas comunidades mencionam o fato de que só não falam em língua indígena com quem não sabe falar. Entendemos esses comentários como uma atitude positiva em relação à própria língua, isto é, é como se eles sentissem que a 
língua indígena é tão boa quanto qualquer outra e por isso pode (ou deve) ser aprendida pelos não indígenas também. No trecho 3, a informante, inclusive, explicita que fica feliz quando alguém se interessa em aprender a língua indígena que ela usa.

Quando discutimos questões relacionadas à preservação e transmissão das línguas, estamos tratando também do grau de vitalidade dessas línguas. A esse respeito, a UNESCO, por meio da publicação do Atlas das Linguas Ameaçadas (MOSELEY, 2010), classifica as línguas em "salva", "vulnerável", "definitivamente ameaçada", "severamente ameaçada", "criticamente ameaçada" e "extinta". Uma língua estaria "salva" quando é falada por todas as gerações e a transmissão intergeracional é ininterrupta; estaria "vulnerável" quando a maioria das crianças fala a língua, mas o uso está restrito a certos domínios; e assim por diante.

Por essa classificação, tomando os depoimentos dos informantes como parâmetro e também o que observamos pessoalmente durante as visitas às comunidades, as línguas indígenas de que estamos tratando estariam "salvas", uma vez que os idosos, os adultos, os jovens e as crianças falam essas línguas, ou seja, a transmissão intergeracional estaria ocorrendo de forma satisfatória.

A situação, entretanto, não é tão simples, uma vez que sabemos que, no caso de línguas consideradas minoritárias, uma afirmação no sentido de que elas estão salvas e por isso não há nenhum problema ou risco seria, no mínimo, ingênua e precipitada. Em outros momentos das entrevistas, alguns informantes mencionam a percepção de preconceito em relação a essas línguas, o que inibe, de certa forma, o uso em alguns contextos.

4. Quando eu estudei no ginásio, aqui na vila Jakarey [distrito de Japorã], eu via que os alunos não indígenas e até os professores não gostavam quando a gente falava em guarani. Não sei... mas parece que eles não gostavam de ouvir, era como se a gente fosse inferior. Dessa forma que eu percebia um tipo de preconceito. (Marcos, 35 anos, Guarani Nandeva)

5. Hoje em dia, aqui na Panambizinho, tem jovem que estuda fora da aldeia, fora da escola da aldeia, e quando volta já tem preconceito pela fala, pela sua própria língua. Fala assim: 'essa língua é de antigamente, 
é feia, eu não quero falar, tem que falar só português'. Isso já aconteceu aqui na Panambizinho. (Antônio, 42 anos, Guarani Kaiowá)

No trecho 4, o informante busca, na memória, no passado, um exemplo de caso em que observava preconceito em relação à sua língua. Ele menciona o espaço da escola que, ao contrário, deveria combater qualquer atitude preconceituosa. Cita, inclusive, a postura dos professores que, para ele, seria preconceituosa. Chama-nos a atenção o fato de o informante avaliar a atitude dos outros alunos e dos professores com as palavras "era como se a gente fosse inferior". Por essas palavras, verificamos que o preconceito não era apenas em relação à língua, mas ao próprio indivíduo.

No decorrer da pesquisa, relatos como esses não foram muito recorrentes. Ou seja, pouco se falou sobre preconceito e discriminação contra as línguas ou a população indígena. É possível que os informantes não quisessem tratar desse assunto, mas é possível também que relatos como o do trecho 4 sejam menos frequentes porque as crianças e os adolescentes indígenas, ao menos das comunidades com as quais trabalhamos, em sua maioria estudam em escolas em que praticamente todos os professores e estudantes são indígenas.

Entendemos que o preconceito tem relação direta com o desconhecimento. Nesse sentido, lembramos as palavras de Albuquerque Junior (2007, p. 10), para quem preconceito são “definições prévias, definições ou descrições que não advêm do conhecimento do outro, mas que nascem da hostilidade, da distância ou do desconhecimento do outro". O mesmo autor acrescenta ainda: "É um conceito apressado, uma opinião, uma descrição, uma explicação, uma caracterização, que vem antes de qualquer esforço verdadeiro no sentido de entender o outro, o diferente, o estrangeiro, o estranho, em sua diferença e alteridade" (ALBUQUERQUE JUNIOR, 2007, p. 11).

No caso desses grupos indígenas, praticamente todos os moradores se conhecem, muitos são amigos próximos e/ ou têm relação de parentesco. Estando entre conhecidos, amigos e parentes, de fato, as situações de preconceito devem ser mais raras. Não podemos afirmar, entretanto, que essas situações não ocorram mesmo no interior do grupo étnico e com estudantes indígenas que estudam fora das aldeias, com professores e colegas não indígenas. 
No trecho 5, o informante menciona um tipo de preconceito que viria de pessoas da própria comunidade. Ele conta que já aconteceu de jovens indígenas saírem da comunidade para estudar fora e depois voltarem com atitudes preconceituosas em relação à língua materna indígena. Diante dessa queixa, pensamos nos motivos que levariam os jovens indígenas a agirem da maneira como relata o informante. Inicialmente, temos que considerar que a maioria da população indígena das duas comunidades, embora esse não seja o caso dos nossos informantes (a maioria professores com salário fixo), vive em condições muito ruins - falta moradia digna, falta comida, falta roupa, falta saúde. E como essa é a situação da maior parte dos indígenas, o que fica no inconsciente das pessoas é que ser índio não é bom. Assim, muitos indígenas vivem o dilema de defender sua cultura, sobretudo sua língua, ou tentar se aproximar cada vez mais do modo de vida do não indígena - o que pode significar, inclusive, o abandono da língua materna. Entendemos, então, que quando um jovem volta para a aldeia dizendo "essa língua é de antigamente, é feia, eu não quero falar, tem que falar só português", duas questões devem ser consideradas: a primeira diz respeito ao fato de os jovens (não indígenas, inclusive) não quererem se parecer com os idosos e, nesse sentido, a língua dos mais velhos não vai lhes interessar; já a segunda diz respeito ao desprestígio que provavelmente notou em relação à língua indígena. Se o jovem retorna dizendo que a língua é "feia", provavelmente já ouviu isso algumas vezes ou, se não chegou a ouvir, certamente sentiu que é o que pensam outras pessoas. Confirmando essa segunda explicação, verificamos o que registra o Referencial Curricular Nacional para as Escolas Indígenas (RCNEI) sobre o assunto:

Uma das maneiras utilizadas por falantes de línguas dominantes para manter o seu poder lingüístico é demonstrar desprezo pelas línguas minoritárias: é referir-se a elas como 'gírias', 'dialetos', 'línguas pobres' ou 'línguas imperfeitas'. Isso faz com que os falantes indígenas passem a se envergonhar de suas línguas, passem a ter atitudes negativas em relação a elas, terminando por abandoná-las (BRASIL, 1998, p. 117).

No mesmo sentido, também contribuem para essa reflexão as palavras de Maher (2010, p.34): 
... foi principalmente devido ao açoite, à ameaça, à intimidação e à depreciação, atos de violência, ora mais, ora menos explícitos, que várias comunidades indígenas brasileiras 'optaram por abandonar' suas línguas tradicionais. É, portanto, imperioso, que esse ‘abandono' seja sempre colocado entre aspas porque uma comunidade de fala não desiste de sua língua livremente. Não é como se ela, racionalmente, pesasse os prós e os contras e, em seguida, tomasse a fria decisão de abandoná-la em favor da língua portuguesa, da língua majoritária.

Essas ponderações expostas no trecho retirado do RCNEI (BRASIL, 1998) e no de Maher (2010) nos ajudam a entender alguns dos motivos pelos quais muitos indígenas, como aquele que volta para a aldeia depois de ter ficado um tempo fora, acabam expressando atitudes negativas em relação às suas línguas tradicionais e, até, querendo substituí-las.

Trouxemos esses dois depoimentos sobre preconceito para a reflexão porque os consideramos significativos e porque, embora o assunto não tenha aparecido com mais frequência durante as entrevistas gravadas, ouvimos de outros jovens que, quando eles saem da aldeia para fazer compras no centro da cidade, por exemplo, e conversam entre eles, muitas pessoas riem e até fazem imitações desagradáveis da língua indígena.

Apesar disso, reiteramos, a julgar pelo discurso declarado acerca das crenças, das práticas e das atitudes da maioria dos entrevistados, o futuro das línguas ${ }^{4}$ indígenas das comunidades investigadas estaria relativamente seguro. Aqui, parece oportuno lembrar que, consoante ao que afirma Manuel Alvar (1986, p. 197), se a língua não se manifestar de maneira muito precisa, os demais comportamentos perdem a possibilidade de serem transmitidos. Assim, podemos pressupor que, nos contextos em que a língua deixa de ser utilizada, outros elementos da cultura também deixam de ser manifestados.

Câmara Jr. (1977, p. 18) afirma que, se por um lado, há ressalvas em se associar diretamente língua e cultura pelo fato de que uma mesma língua pode servir a culturas distintas, por outro lado não há como negar a relação entre uma e outra. $\mathrm{O}$ autor explica que a língua é parte de um todo - nesse

${ }^{4}$ Lembramos que Fasold (1984) afirma que as atitudes em relação ao futuro de uma língua é um dos objetos de estudos de atitudes sobre a linguagem. 
caso, da cultura, mas, ao mesmo tempo, desse todo ela se destaca, uma vez que é pela língua que os demais elementos da cultura são veiculados. Essa ideia costuma ser demonstrada por meio da conhecida figura que reproduzimos a seguir.

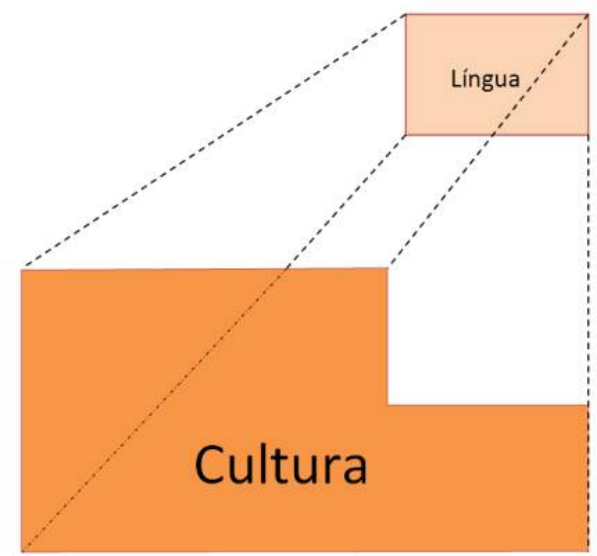

Fonte: Câmara Jr. (1977, p. 18).

Figura 1 - Língua e cultura

Além de ser o elemento mais importante da cultura, de acordo com a fala do informante no trecho 1 , a língua também é o constituinte principal da identidade: “O que é uma pessoa sem língua? É morto, né? Sem identidade". As palavras do trecho 3 também vão ao encontro do que afirma Câmara Jr. (1977): "A língua é o que temos de mais importante, né? Sem a língua não tem reza, não tem canto, não tem festa”.

Diante do exposto, entendemos que os indígenas estão conscientes da necessidade de se preservar e ensinar a língua materna às novas gerações; esse parece ser um desejo de todos os falantes das duas comunidades, segundo os informantes.

Evidentemente concordamos com os informantes e com os autores que trouxemos para esta reflexão no que se refere à relação entre língua e cultura, língua e identidade. Vale a pena recuperar, entretanto, ainda que 
brevemente, a discussão proposta por Maher (1998), em seu texto intitulado "Sendo índio em português...", no qual a autora discorre sobre a situação linguística de grupos étnicos indígenas do estado do Acre. Ela inicia afirmando que ninguém discordaria que a língua portuguesa não é o "símbolo tradicional de indianidade” (MAHER, 2006, p. 115). E, no decorrer de seu texto, relata que indígenas do Acre utilizam uma variedade da língua portuguesa que os caracteriza e, por isso, passa a ser também relacionada à construção de identidade indígena. Isso porque, segundo a autora, "a construção da identidade não é de domínio exclusivo de língua alguma" e "um português índio também pode marcar a identidade de seus falantes" (MAHER, 2006, p. 134-135).

O contexto linguístico dos índios a que a autora se refere não é idêntico ao dos grupos com os quais trabalhamos no Mato Grosso do Sul, sobretudo porque ela relata que a principal preocupação daquelas comunidades era recuperar a língua indígena, que já estaria praticamente esquecida pela maioria dos indígenas. Apesar disso, é preciso ter em vista, porque isso tem implicações no processo de ensino/aprendizado formal das escolas, que o português utilizado pela maioria dos índios dos dois subgrupos Guarani do Mato Grosso do Sul, assim como o português dos indígenas do Acre, é uma variedade com características particulares.

Neste trabalho, já afirmamos que os dois subgrupos étnicos com os quais trabalhamos têm como primeira língua uma língua indígena (guarani kaiowá ou guarani ñandeva) e que o nível de transmissão, segundo os informantes, estaria adequado. Qual seria, então, o lugar da língua portuguesa, que é segunda língua de todos os informantes desta pesquisa e da grande maioria dos moradores daquelas comunidades?

\subsection{Sobre a importância do aprendizado da lingua portuguesa}

Solicitamos aos informantes que nos relatassem em que medida eles consideravam importante que os indígenas de suas comunidades aprendessem a língua portuguesa. Todos os entrevistados declararam que consideram relevante que todos, inclusive as crianças, dominassem também a língua portuguesa. Os trechos a seguir são exemplos das respostas dadas a essa questão. 
6. É muito importante aprender português porque ninguém mais fica só aqui na aldeia, sai para cidade, para outros lugares e tem que saber português para viajar de ônibus. Por causa do contato; se não fosse isso, se fosse só viver aqui na aldeia não precisava de português, mas não é assim. (Marcos, 35 anos, Guarani Nandeva)

7. A gente vive no Brasil e a língua oficial do Brasil é o Português. A gente não vive mais isolado. A gente precisa e quer também se comunicar com outras pessoas, ver televisão, viajar, conhecer outros lugares. E isso não quer dizer abandonar cultura do índio, como algumas pessoas mais ignorantes pensam que é. Meu desejo é que meus filhos aprendem as duas línguas. (Fábio, 27 anos, Guarani Kaiowá)

8. Eu fico feliz em ver uma criancinha falando guarani, mas mais para frente ela vai ter que aprender o português para se comunicar com outras pessoas não indígenas, na escola, por exemplo, fora. Tem que aprender para ter acesso a outras coisas, à internet, por exemplo... (Sandra, 28 anos, Guarani Ñandeva)

9. Minha mãe até preferiu que minha irmã, que tem sete anos, fosse estudar na escola da vila porque lá ela aprende melhor o português. É longe, mas aprende mais falar português. (Flávia, 21 anos, Guarani Kaiowá)

No trecho 6, o informante explicita que o domínio da língua portuguesa está relacionado à necessidade de sair da aldeia, de usar um ônibus, por exemplo - é possível que ele esteja se referindo à necessidade de ler a indicação de um itinerário de ônibus ou mesmo solicitar uma informação. Assim, de acordo com esse informante, a motivação para que os indígenas aprendam o português está totalmente ligada à situação de contato a que estão submetidos, o que é mais evidente na passagem do trecho: "se fosse só viver aqui na aldeia não precisava de português".

O fato de a língua portuguesa ser a língua oficial do Brasil é lembrado como argumento pelo informante Guarani Kaiowá, no trecho 7, em favor do aprendizado dessa língua. Mas parece ser, novamente, a necessidade e o 
desejo de contato com outras pessoas e outros lugares a motivação principal para se aprender português. Esse informante garante que aprender uma segunda língua não significa abandonar sua língua materna, sua cultura tradicional.

No trecho 8, a informante também se refere ao fato de as pessoas terem que sair da aldeia e se comunicarem com outras pessoas que falam português. Ainda conforme esse depoimento, já na escola (citada, por outro informante, como aliada da língua materna) a criança precisará se comunicar em língua portuguesa. Ela cita também a necessidade de saber português para acessar a internet, que é recurso relativamente acessível nas duas comunidades com as quais trabalhamos.

Podemos constatar, no trecho 9, que a informante declara que a preocupação de sua família com o aprendizado da língua portuguesa é tão grande que a mãe preferiu que a filha menor fosse estudar em escola não indígena, fora da aldeia, mais longe de casa inclusive, para terem uma garantia de que a menina aprenda melhor a segunda língua. Lembramos que essa preocupação foi explicitada por uma informante Guarani Kaiowá, da aldeia Panambizinho.

Entre os Guarani Ñandeva da aldeia Porto Lindo, também constatamos, durante as entrevistas, que a preocupação dos pais em relação ao domínio da língua portuguesa pelas crianças estaria tão presente que eles teriam chegado a ser contra o ensino de guarani nas escolas indígenas, conforme explica o informante.

10. No início, os pais não queriam o ensino na língua materna (indígena), mas porque eles não tinham entendido bem, eles pensavam que a gente só ia ensinar e escrever só em guarani, mas aí nós fomos explicando que a gente ensinaria as palavras que não estão sendo mais utilizadas, do guarani tradicional mesmo, e que o português também ia ter. Aí, aos poucos, eles foram entendendo. (Marcos, 35 anos, Guarani Nandeva)

Esse informante explica que os pais queriam que as crianças fossem para a escola "aprender o que não sabiam direito", isto é, a língua portuguesa. Ler e escrever em língua indígena as crianças também não sabiam, entretanto 
não parecia tão importante na percepção dos pais. O informante conta que, aos poucos, com um trabalho de esclarecimento contínuo às famílias dos estudantes, os professores da escola conseguiram fazer com que todos entendessem e aceitassem a proposta.

Nessa reflexão, convém mencionar o que registra o RCNEI (BRASIL, 1998, p. 117):

A inclusão de uma língua indígena no currículo escolar tem a função de atribuir-lhe o status de língua plena e de colocá-la, pelo menos no cenário escolar, em pé de igualdade com a língua portuguesa, um direito previsto pela Constituição Brasileira.

Quando as línguas ficam restritas a usos orais podem permanecer em posições de pouco prestígio e de baixa funcionalidade, o que diminui suas chances de sobrevivência em situações de pós-contato. Além disso, ensinar uma língua indígena obrigatoriamente na escola, também em sua modalidade escrita, é reconhecer que ela é tão boa e eficiente quanto a língua majoritária e que, por essa razão, pode ser objeto de estudo e reflexão na escola.

A questão da conciliação entre a língua indígena materna e a língua portuguesa como segunda língua, entretanto, nem sempre escapa a algumas polêmicas e costuma ser assunto recorrente em pesquisas que tratam da situação linguística de povos indígenas brasileiros em contato.

Maher (2010, p. 40), por exemplo, discutindo sobre o futuro das línguas indígenas acreanas e o papel da língua portuguesa no currículo escolar, relata que os professores, durante os cursos de formação, aprendiam português e traziam essa língua para a aldeia. Com isso, os outros membros também se interessavam em aprender e ensinar para os filhos pequenos. A motivação, nesse caso, seria a possibilidade de "ocupar posições de prestígio social nas aldeias" e "possuir cargos assalariados". No extremo, naquele contexto, alguns pais estariam, inclusive, deixando de falar em língua indígena com suas crianças para que o aprendizado da língua portuguesa fosse mais eficiente e rápido. Isso seria um sério problema para as línguas indígenas da região. A autora, no entanto, acrescenta: 
Vários professores argumentaram que, embora esse tipo de procedimento representasse uma ameaça à sobrevida das línguas indígenas locais, por outro lado, ele era legítimo porque também favorecia a sobrevida de seus povos, já que o domínio da língua portuguesa era necessário para que eles pudessem se defender no confronto com a sociedade envolvente (MAHER, 2010, p. 40).

Essa menção à situação de indígenas do Acre, relatada por Maher (2010), apenas confirma a consciência da importância da língua portuguesa. Para esses indígenas, o domínio da língua portuguesa está ligado à chance de ascender socialmente, melhorar de vida, se defender em eventuais confrontos.

$\mathrm{Na}$ mesma direção, em todos os depoimentos coletados com os informantes de nossa pesquisa, fica evidente que as razões pelas quais se deseja e se deve aprender a segunda língua, o português, têm relação com as exigências da vida prática, especialmente fora da comunidade. Assim, constatamos que as motivações dos indígenas do Acre e dos de Mato Grosso do Sul são muito semelhantes.

Nesse contexto, lembramos a situação descrita por Alvar (1986, p. 228) que, discutindo as preferências linguísticas de indivíduos de Porto Rico, que têm como língua materna o espanhol, menciona o primeiro motivo apontado pelos porto-riquenhos para aprender a segunda língua, o inglês: o pragmatismo. De acordo com esse pesquisador, seus entrevistados citam motivos relacionados à conveniência de saber uma segunda língua, motivos relacionados a questões práticas e concretas do cotidiano.

Machado (2013, p. 216), relatando pesquisa realizada na Reserva Indígena Francisco Horta (Dourados/MS), lembra que o contato permanente dos indígenas com o entorno e a necessidade de comunicação na língua dominante é motivo forte para que os indivíduos procurem aprender a segunda língua. De acordo com esse pesquisador, que é indígena, professor de escola indígena do município de Dourados,

... a necessidade pela sobrevivência leva a buscar oportunidades melhores de trabalho, aprendizado de profissões liberais para atuarem nos centros urbanos. Nisso parece estar a solução dos problemas atuais, haja vista que a comunidade possui pouca terra para o cultivo agrícola. 
Dizendo em outras palavras, por não ser possível viver como viviam os antepassados, é necessário buscar alternativas. Todavia, para que isso aconteça é imprescindível o aprendizado da língua portuguesa (MACHADO, 2013, p. 216).

Nossa pesquisa confirma o que já havia observado Alvar (1986) nesse caso sobre a relação do espanhol e do inglês -, Maher (2010) e Machado (2013) sobre os motivos pelos quais muitos falantes querem aprender uma segunda língua, que tem prestígio. Convém destacar, no entanto, que muitos dos nossos informantes afirmam também que, se não fosse por conveniência e por necessidade de sair da aldeia - já que não é mais possível reproduzir completamente o modo de vida tradicional -, o interesse pelo português seria menor entre muitos indígenas.

Outra motivação para o aprendizado da língua portuguesa, que esperávamos encontrar nas falas dos informantes, é a que está ligada à compreensão das leis que regem o país e, evidentemente, têm relação com os direitos da população indígena. Entretanto, essa preocupação aparece apenas implicitamente nas falas dos informantes desta pesquisa. O RCNEI, sobre essa questão, registra:

Aprender e saber usar a Língua Portuguesa na escola é um dos meios de que as sociedades indígenas dispõem para interpretar e compreender as bases legais que orientam a vida no país, sobretudo aquelas que dizem respeito aos direitos dos povos indígenas. Todos os documentos que regulam a vida da sociedade brasileira são escritos em português: as leis, principalmente a Constituição, os regulamentos, os documentos pessoais, os contratos, os títulos, os registros e os estatutos. Os alunos indígenas são cidadãos brasileiros e, como tais, têm o direito de conhecer esses documentos para poderem intervir, sempre que necessitarem, em qualquer esfera da vida social e política do país (BRASIL, 1998, p. 121).

Se, por um lado, a referência à necessidade de acesso e compreensão das "bases legais que orientam o país" não aparece diretamente nos depoimentos dos nossos entrevistados, por outro lado verificamos que, 
quando os informantes mencionam a necessidade de sair, de pegar ônibus, de ir à escola, de usar internet, estão preocupados em participar efetivamente de diferentes "esferas da vida social do país", o que pressupõe o domínio efetivo da língua portuguesa.

Também Mattos e Silva (2004), discutindo sobre "A diversidade do português brasileiro e seu ensino aos povos indígenas", lembra que ser um falante que domine modalidades distintas do português, que tenha consciência do que é adequado para cada situação de comunicação pode significar força para os indígenas na luta pelos seus direitos:

... qualquer política lingüística que se trace hoje, em favor do índio brasileiro, dever-se-ia levar em consideração o significado político de um treinamento lingüístico das lideranças para o domínio do dialeto padrão, entendido no seu sentido amplo, que envolva não só a transmissão das regras gramaticais do dialeto socialmente privilegiado, mas também o desenvolvimento do domínio do adequado/nãoadequado às diversas situações sociopolíticas; isto, no âmbito do entendimento da linguagem como instrumento não apenas de comunicação, mas de persuasão, isto é, no caso, como instrumento ou arma que favoreça o índio na luta por seus direitos (MATTOS E SILVA, 2004, p. 45).

Nos trechos retirados do RCNEI (BRASIL, 1998) e também nas palavras de Mattos e Silva (2004), estariam motivos suficientes em favor do domínio da língua portuguesa em sua modalidade específica utilizada pelos indígenas, mas também em sua modalidade considerada privilegiada.

Ainda sobre essa questão, vale registrar, uma vez que o discurso difere um pouco dos demais, que um dos entrevistados minimiza a importância da língua portuguesa para a comunidade indígena, alegando que não considera muito importante aprender a segunda língua desde pequeno.

11. Eu acho importante aprender português, mas não é muito importante aprender desde pequeno. Só com 14, 15 anos que as pessoas começavam a ter que sair aqui da aldeia. Eu só aprendi português com 15 anos. (Antônio, 42 anos, Guarani Kaiowá) 
Como se observa, na opinião do entrevistado, que é professor e coordenador pedagógico, as crianças indígenas Guarani Kaiowá, poderiam deixar para aprender português um pouco mais tarde, quando realmente precisassem sair da comunidade. Em todo caso, esse informante também explicita a necessidade de aprender a segunda língua para interagir com a comunidade externa.

\section{Considerações Finais}

Como pudemos constatar, por meio das falas dos informantes, o nível de transmissão da língua indígena nas duas comunidades estaria adequado, uma vez que todas as crianças pequenas aprendem a língua materna em casa, com a família, e também na escola, com os professores. Alguns informantes, inclusive, apontam as escolas, que inseriram a língua indígena no currículo, como aliadas na manutenção e valorização das línguas indígenas. Apesar disso, não é possível afirmar que as línguas maternas dessas comunidades, assim como as de quaisquer outras comunidades indígenas, não correm nenhum tipo de risco quanto à diminuição de uso ou à extinção. Alguns entrevistados relatam situações de desprestígio e de preconceito contra suas línguas maternas. Essas situações podem favorecer o aparecimento de sentimento e atitudes negativas em relação à própria língua. Nesses casos, aos poucos, os falantes tendem a restringir o uso da língua materna a apenas alguns contextos e isso poderá deixá-la em situação de vulnerabilidade.

Lembramos novamente, consoante ao que afirma Maher (2010, p. 34), que a intimidação e a depreciação, por exemplo - algumas vezes explícitas, outras nem tanto -, são fatores que levaram comunidades indígenas, inclusive ao abandono de suas línguas tradicionais. Por essa razão, muitos esforços ainda deverão ser empreendidos até que possamos eliminar esse tipo de preconceito e todos possam entender que as línguas indígenas são tão adequadas para a comunicação como quaisquer outras.

Observamos, contudo, que o nível de transmissão da língua materna é adequado porque todas as gerações a utilizam. Durante nossa pesquisa e visitas às comunidades indígenas, observamos também que, com exceção de alguns idosos, todos os falantes são bilíngues, porque, além da língua materna, utilizam também a língua portuguesa como segunda língua. $\mathrm{Na}$ 
aldeia Porto Lindo, que fica próxima à fronteira com o Paraguai, alguns indígenas, além do português e do guarani, utilizam também o espanhol em certas situações de interação (com falantes paraguaios, por exemplo).

Os depoimentos analisados também deixaram evidente que o aprendizado da língua portuguesa (como segunda língua) é considerado importante pelos informantes, principalmente pela necessidade do contato fora das comunidades indígenas. Os entrevistados afirmam, por exemplo, nos trechos transcritos neste trabalho, que os indígenas precisam tomar ônibus, pedir informações, ser atendidos no centro da cidade e também desejam usufruir de bens que não estão disponíveis em língua indígena, como a internet.

A pesquisa mostrou que o domínio da língua portuguesa, além de ser direito e desejo das comunidades investigadas, constituídas de cidadãos brasileiros, é uma necessidade para a sobrevivência dessa população. Além disso, entendemos que o que registra o RCNEI (BRASIL, 1998, p. 12), sobre essa questão deverá sempre estar em vista, ou seja, o domínio eficiente da língua portuguesa também permite que os indígenas acessem e compreendam os documentos oficiais que garantem seus direitos, inclusive o direito de intervirem em qualquer esfera da vida social e política do país.

Aqui convém registrar que, por "domínio eficiente", estamos entendendo o alcance mais próximo quanto possível da modalidade considerada culta. No entanto, não se pode perder de vista que cada grupo indígena (e muitos não indígenas também) utiliza a língua portuguesa com algumas características específicas, em geral relacionadas à sua língua materna. Essa língua portuguesa, com marcas específicas que servem aos indígenas nas situações de contato com a sociedade não indígena, também faz parte da sua identidade de índio da atualidade, e ele deve ser considerada no planejamento das atividades escolares.

Acreditamos que, se este trabalho tiver sido útil para a compreensão de ao menos uma parte da realidade linguística dos dois grupos indígenas estudados, terá cumprido seu principal objetivo. 


\section{Referências}

ALBUQUERQUE JR, D. M. Preconceito contra a origem geográfica e de lugar: fronteiras da discórdia. São Paulo: Cortez, 2007.

ALVAR, M. Hombre, etnia e estado - actitudes lingüísticas em hispanoamérica. Madri: Gredos, 1986.

BRASIL. Ministério da Educação e do Desporto. Secretaria de Educação Fundamental. Referencial Curricular Nacional para as Escolas Indigenas RCNEI. Brasília: MEC; SEF, 1998.

CÂMARA JR., J. M. Introdução às línguas indígenas brasileiras. 3. ed. Rio de Janeiro: Ao Livro Técnico, 1977.

FASOLD, R. The sociolinguistics of society. Oxford: Basil Blackwell, 1984.

INSTITUTO BRASILEIRO DE GEOGRAFIA E ESTATÍSTICA IBGE. Censo 2010. Disponível em: < http://bit.do/cUGha>. Acesso em: 03 set. 2014.

MOSELEY, C. Atlas of the World's Languages in danger. 2010. Disponível em: <http://bit.do/cUGhf>. Acesso em: 20 jan. 2014.

MACHADO, J. Tetã Kaiowá (Pátria Guarani): uma perspectiva históricolinguística. In: PEREIRA, M. C. (Org.). Tetã-Guarani: pelos caminhos sul de Mato Grosso do Sul. Campo Grande, MS: Life, 2013.

MAHER, T. M. Sendo índio em português... In: SIGNORINI, I. (Org.). Lingua(gem) e identidade: elementos para uma discussão no campo aplicado. São Paulo: Mercado das Letras, 1998.

MAHER, T. M. Políticas linguísticas e políticas de identidade: currículo e representações de professores indígenas na Amazônia ocidental brasileira. Currículo sem Fronteiras, v. 10, n. 1, p. 33-48, jan./jun. 2010.

MARCONI, M. de A.; LAKATOS, E. M. Fundamentos de metodologia científica. 7. ed. São Paulo: Atlas, 2010. 
MARTINS, G. R. Breve painel etno-histórico de Mato Grosso do Sul. 2. ed. ampl. e revis. Campo Grande, MS: Ed. UFMS, 2002.

MATTOS E SILVA, R. V. A diversidade do português brasileiro e seu ensino aos povos indígenas. In: MAT'TOS E SILVA, R. V. O português são dois...: novas fronteiras, velhos problemas. São Paulo: Parábola, 2004. p. 37-46.

TAVARES, M. Um estudo das etnias Guarani Kaiowá e Guarani Ñandeva a partir de suas impressões sobre as línguas e de um recorte do léxico em uso. 2015. Tese (Doutorado em Estudos da Linguagem) - Universidade Estadual de Londrina, Londrina.

Recebido em: 15/01/2016 Aceito: 29/04/2016 